\title{
Potential biotic-abiotic nitrous oxide production in oceanic oxyclines
}

\author{
AMANDA R. CAVAZOS ${ }^{1 *}$, JENNIFER B. GLASS ${ }^{2}$
}

${ }^{1}$ Georiga Institute of Technology, Atlanta, GA, USA;

(*correspondence:acavazos3@gatech.edu)

${ }^{2}$ Georiga Institute of Technology, Atlanta, GA, USA;

(jennifer.glass@eas.gatech.edu)

Nitrous oxide $\left(\mathrm{N}_{2} \mathrm{O}\right)$ is a potent greenhouse gas that depletes stratospheric ozone. Most oceanic $\mathrm{N}_{2} \mathrm{O}$ emissions are from oxygen minimum zones (OMZs), where oxygen concentrations fall below detection. Incomplete denitrification at the oxycline is thought to be the largest source of $\mathrm{N}_{2} \mathrm{O}$ in OMZs. However, $\mathrm{N}_{2} \mathrm{O}$ can be produced by abiotic reactions between nitrogenous intermediates and metal oxides. Hydroxylamine $\left(\mathrm{NH}_{2} \mathrm{OH}\right)$, an intermediate of ammonia oxidation, can rapidly react with manganese $(\mathrm{Mn})$ oxides $\left(\mathrm{NH}_{2} \mathrm{OH}\right.$ chemo-oxidation) to produce $\mathrm{N}_{2} \mathrm{O}$. We provide evidence that $\mathrm{NH}_{2} \mathrm{OH}$ chemo-oxidation by birnessite, a ubiquitous $\mathrm{Mn}$ oxide, rapidly and effectively produces $\mathrm{N}_{2} \mathrm{O}$ in marine conditions. Conversion to $\mathrm{N}_{2} \mathrm{O}$ occurs within three minutes and goes to completion. We provide preliminary evidence that the necessary substrates for $\mathrm{NH}_{2} \mathrm{OH}$ chemooxidation could occur at oxyclines. We developed a method that uses SYBR Green and leucoberblin blue simultaneously to locate microbial cells and $\mathrm{Mn}$ oxide particles on filters (simul-staining) with differential interference contrast and epifluorescent microscopy. Simul-staining filters from the Gulf of Mexico OMZ found microbial cells associated with manganese oxide particles. While cells could not be identified, they exhibit similar morphology and size to ammonia-oxidizing archaea prevously found in the Gulf of Mexico OMZ. Our findings suggest that biotic-abiotic production of $\mathrm{N}_{2} \mathrm{O}$ could occur in OMZs.

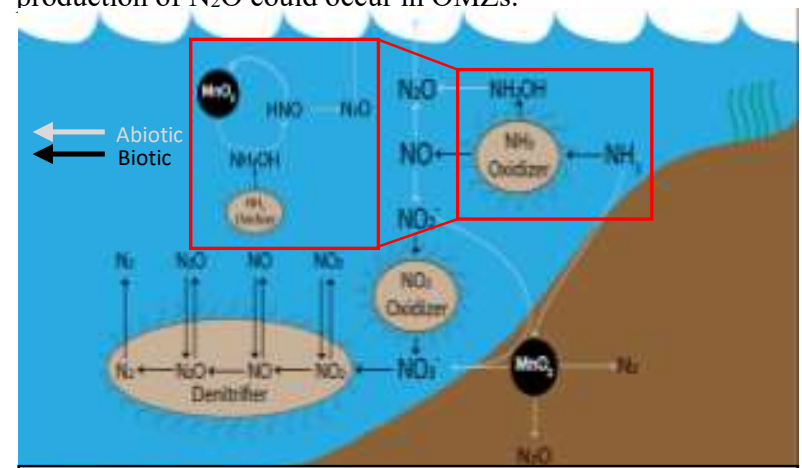

Figure 1. As ammonia is oxidized by ammonia-oxidizing microbes, $\mathrm{NH}_{2} \mathrm{OH}$ leaks out and reacts with $\mathrm{Mn}$ oxides to produce $\mathrm{N}_{2} \mathrm{O}$. 